\title{
PROTOCOL
}

\section{ExplorinG frailty and mild cognitive impairmEnt in kidney tRansplantation to predict biomedicAl, psychosocial and health cost outcomeS (GERAS): protocol of a nationwide prospective cohort study}

\author{
Oliver Mauthner, Veerle Claes, Jeremy Walston, Sandra Engberg, Isabelle Binet, Michael \\ Dickenmann, Déla Golshayan, Karine Hadaya, Uyen Huynh-Do, Stefano Calciolari, Sabina De Geest, \\ For the GERAS study consortium; For the Psychosocial Interest Group; Swiss Transplant Cohort \\ Study (STCS)
}

Correspondence to O. Mauthner:

e-mail: oliver.mauthner@unibas.ch

See Appendix 1.

Oliver Mauthner PhD RN

Postdoctoral Fellow

Institute of Nursing Science, University of Basel, Switzerland

Veerle Claes MScN RN

$\mathrm{PhD}$ Student and Research Assistant Institute of Nursing Science, University of Basel, Switzerland

Jeremy Walston MD PhD

Professor of Geriatric Medicine and Deputy Director

Center on Aging and Health, Johns Hopkins University, Baltimore, Maryland, USA

Sandra Engberg PhD RN

Professor and Associate Dean for Graduate Clinical Education Health Promotion \& Development/Visiting Professor Institute of Nursing Science, University of Basel, Switzerland

School of Nursing, University of Pittsburgh, Pennsylvania, USA

continued on page 717
MAUthner O., Claes V., WAlston J., ENGBERG S., Binet i., DiCKenMANN M., GOLSHAYAN D., HADAYA K., HUYNH-DO U., CALCIOLARI S. \& DE GEEST S. FOR THE GERAS STUDY CONSORTIUM; FOR THE PSYCHOSOCIAL INTEREST GROUP; SWISS TRANSPLANT COHORT STUDY (STCS) (2017) ExplorinG frailty and mild cognitive impairmEnt in kidney tRansplantation to predict biomedicAl, psychosocial, and health cost outcomeS (GERAS): protocol of a nationwide prospective cohort study. Journal of Advanced Nursing 73(3), 716-734. doi: 10.1111/jan.13179

\begin{abstract}
Aim. To present the rationale, design and methodology of the GERAS project, which examines whether assessment of frailty and mild cognitive impairment could enhance risk prediction for biomedical, psychosocial outcomes and foster efficient resource allocation in kidney transplantation.

Background. For the burgeoning cohort of older patients considered for kidney transplantation, evidence gaps regarding frailty and mild cognitive impairment limit clinical decision-making and medical management. As known risk factors for 'hard' clinical outcomes in chronic illness, both require further study in transplantation. Integrating these and other bio-psychosocial factors into a comprehensive pre-transplant patient assessment will provide insights regarding economic implications and may improve risk prediction.

Design. A nation-wide multi-centre prospective cohort study nested in the Swiss Transplant Cohort Study.

Methods. Our nationally representative convenience sample includes 250 adult kidney transplant recipients. Data sources include the Swiss Transplant Cohort Study and primary data collected at time of transplantation, 6 months, 1 and 2 years posttransplant via established measures (the Montreal Cognitive Assessment, Psychosocial Questionnaire, Fried Frailty Instrument and a blood analysis), investigator-developed instruments and datasets compiled by hospitals' management control units, sickness funds, the Swiss Federal Statistical Office and the European Renal Association.
\end{abstract}


Isabelle Binet MD

Chief Physician

Clinic of Nephrology and Transplantation

Medicine, Cantonal Hospital St Gallen, Switzerland

Michael Dickenmann MD PhD

Chief Physician

Department for Transplantation-

Immunology and Nephrology, University

Hospital Basel, Switzerland

Déla Golshayan MD PhD

Senior Physician and Head of Research Transplantation Centre and Transplantation Immunopathology Laboratory, University Hospital Lausanne, Switzerland

Karine Hadaya MD PhD

Deputy Chief

Department of Nephrology, University

Hospital Geneva, Switzerland

Uyen Huynh-Do MD

Associate Professor

University Clinic for Nephrology,

Hypertension and Clinical Pharmacology,

University Hospital Bern, Switzerland

Stefano Calciolari PhD

Assistant Professor

Institute of Economics, University of

Lugano, Switzerland

Sabina De Geest PhD RN

Professor and Director

Institute of Nursing Science, University of

Basel, Switzerland

Academic Center for Nursing and

Midwifery, KU Leuven, Belgium
Descriptive, competing risk survival and mixed effects analyses will be performed. Research Ethics Committee approval was obtained in January 2016.

Discussion. This pioneering project jointly examines frailty and mild cognitive impairment from bio-psychosocial and health economic perspectives. Results may significantly inform risk prediction, care tailoring and resource optimization to improve health outcomes in the ageing kidney transplant cohort.

Keywords: frailty, health economics, kidney transplantation, midwives, mild cognitive impairment, nurses, nursing, older patients, risk prediction, multi-centre prospective cohort study

\section{Why is this study or review needed?}

- Despite rising numbers of older adults being evaluated for and undergoing kidney transplantation, there is a lack of evidence to guide risk prediction for this cohort.

- Preliminary evidence indicates that frailty and mild cognitive impairment are highly prevalent and are independent predictors of adverse biomedical outcomes in kidney transplantation

- The GERAS study is the first to examine frailty and mild cognitive impairment from a comprehensive bio-psychosocial and health economic perspective. It will provide evidence for healthcare professionals to better identify patients most at risk for adverse outcomes. This can guide early intervention and tailor pre- and posttransplant care, policy development and resource allocation, aiming to improve outcomes for the growing cohort of elderly and frail kidney transplant recipients

\section{Introduction}

Increasing numbers of older patients with end-stage renal disease (ESRD) are receiving kidney transplants (Abecassis et al. 2012, Goldstein 2012, McAdams-Demarco et al. 2013a). Even in countries where age directly limits graft access, kidney transplantation $(\mathrm{KTx})$ populations are greying (European Renal Association - European Dialysis and Transplant Association (ERA-EDTA), 2013, United Network for Organ Sharing (UNOS) - Organ Procurement and Transplantation Network (OPTN), 2014a). Older patients' medical needs, however, present major challenges for the KTx healthcare agenda, as there is limited evidence to guide clinical decision-making for organ allocation, and pre- and posttransplant management in this cohort. Therefore, exploring outcome-predictive factors in older KTx patients is a rapidly rising research priority (Abecassis et al. 2012, Goldstein 2012, Singh et al. 2016). In Switzerland, where chronological age is not a listing criterion for kidney transplantation, over one-fifth (ca. $22.5 \%$ ) of recipients are aged $\geq 65$ years at time of transplantation ( $\mathrm{Tx}$ ) (Koller et al. 2014). This gives Swiss transplant centres broad opportunities to study this older cohort's outcomes. 


\section{Background}

Frailty as a risk prediction criterion for older KTx patients Growing evidence suggests that, independent of chronological age and comorbidities, frailty can guide risk prediction in chronically ill patient groups (Makary et al. 2010, Flint et al. 2012, Hamaker et al. 2012, Partridge et al. 2012, Dunlay et al. 2014, Lai et al. 2014a, Jha et al. 2015, Musso et al. 2015, Robinson et al. 2015, Singer et al. 2015). While frailty and comorbidities frequently co-exist, they are distinct conditions with independent predictive values regarding adverse outcomes (Fried et al. 2004, DanonHersch et al. 2012, Clegg et al. 2013, Chen et al. 2014). Comorbidity is the simultaneous or sequential occurrence and interaction of two or more disorders in the same patient; frailty is a cumulative functional decline across physiological systems, limiting the body's resilience against stressors. For example, responding to surgical procedures, immunosuppressive medications, or infections, frail patients experience disproportional deterioration in health status and adverse outcomes (Fried et al. 2001, Clegg et al. 2013, Chen et al. 2014). Preliminary findings from longitudinal studies using the Fried Frailty Phenotype (Fried et al. 2001) indicate that frail and pre-frail patients with ESRD and solid organ $\mathrm{Tx}$ recipients have inferior clinical outcomes, for exampl, higher rates of dialysis re-initiation, early hospital readmission and posttransplant mortality.

While KTX-specific links between frailty and such outcomes is based on a single US patient cohort (GaronzikWang et al. 2012, Roshanravan et al. 2012, Johansen et al. 2013, McAdams-Demarco et al. 2013a,b, 2015b, Exterkate et al. 2016, Lam \& Jassal 2015, Musso et al. 2015, Singer et al. 2015, Jha et al. 2016a, Wilson et al. 2016), these findings are extremely relevant: up to $42 \%$ and $29 \%$ of adult haemodialysis patients are respectively pre-frail or frail (Johansen et al. 2013, Musso et al. 2015); and respectively $25 \%$ and $33 \%$ of adult KTx recipients present with frailty or pre-frailty (Garonzik-Wang et al. 2012, McAdams-Demarco et al. 2013a,b, 2015b).

Importantly, as frailty also occurs in younger adults with ESRD and accelerated metabolic ageing (Kooman et al. 2014, Musso et al. 2015), it is relevant across age groups. In 2016, the International Society for Heart and Lung Transplantation became the first international $\mathrm{Tx}_{\mathrm{x}}$ body to integrate frailty into its heart $\mathrm{Tx}$ listing criteria (Comans et al. 2016). Still, while the American College of Surgeons has published guidance to integrate frailty assessments into the care of older surgical patients (Robinson et al. 2015), no clinical practice guidelines yet exist to integrate frailty assessment into KTx care.
Frailty in KTx: applying a bio-psychosocial perspective and studying mild cognitive impairment (MCI)

Interplay between biomedical, psychosocial and behavioural factors determines Tx patients' risks regarding adverse outcomes. Psychosocial factors also independently predict poor posttransplant outcomes (Denhaerynck et al. 2005, Mehra et al. 2006, Dobbels et al. 2008, Gordon et al. 2009, Pinsky et al. 2009, Garg et al. 2012, De Geest et al. 2013, 2014, Pascual et al. 2014). In addition, as patient-reported outcomes, for example, health-related quality of life (HR-QOL), are increasingly valued in KTx research (Molnar-Varga et al. 2011, De Geest et al. 2013, Kumnig et al. 2014, Seiler et al. 2015), comprehensive bio-psychosocial pre-Tx evaluations are endorsed by international $\mathrm{Tx}$ societies and included in KTx clinical management guidelines (Sharing) (Mehra et al. 2006, Pascual et al. 2014).

While pre-frailty and frailty are consistently associated with poorer HR-QOL in non-Tx populations (Kojima et al. 2016), frailty studies in Tx have thus far accounted mainly for biomedical Tx risk factors (McAdams-Demarco et al. 2013a,b, 2015b, Singer et al. 2015). As a predictor of HRQOL, only one study has compared frailty with liver disease severity (Derck et al. 2015). To examine how frailty data can improve bio-psychosocial risk prediction in $\mathrm{KTx}$, prospective pre- to post-Tx studies are essential.

Furthermore, emerging evidence links frailty with MCI, a measurable decline in cognitive function that is excessive relative to a patient's chronological age and educational background but allows basic daily life activities (Apostolo et al. 2015) (Auyeung et al. 2011, Yassuda et al. 2012, Kelaiditi et al. 2013, Halil et al. 2015, Jha et al. 2016a). Up to $55.0 \%$ of adult ESRD patients exhibit MCI, which independently predicts hospital readmissions and mortality in older adults (Auyeung et al. 2011, Drame et al. 2011, Jacobs et al. 2011, Cano et al. 2012, Yassuda et al. 2012). Although cognitive deficits primarily improve posttransplant, they may also persist (Griva et al. 2006, Van Sandwijk et al. 2015, Dixon et al. 2016). Recently, MCI was linked with frailty in haemodialysis patients (McAdamsDemarco et al. 2015c); and in end-stage heart failure, assessing MCI alongside frailty improved mortality prediction (Jha et al. 2016b). Joint examinations of frailty and MCI in KTx are needed to clarify their interrelationships and synergistic predictivity regarding negative outcomes.

\section{Frailty and MCI in KTx: the need for a bealth economic perspective}

While dialysis and KTx are both extremely costly, KTx is clearly more cost-effective (Ferguson et al. 2015, SanchezEscuredo et al. 2015). However, as KTx demands 
significantly exceed graft availability, fair allocation demands risk prediction models that predict both personal and societal costs. Through reliable analyses of resources used and health outcomes, health economic analyses can optimize healthcare resource allocation (Wong et al. 2014, Drummond et al. 2015, Ferguson et al. 2015, SanchezEscuredo et al. 2015). As frailty is a long-term condition with adverse patient and healthcare system outcomes, frail, and pre-frail older non-institutionalized patients use more healthcare resources than their non-frail counterparts (Sirven \& Rapp 2014, Harrison et al. 2015, Ilinca \& Calciolari 2015, Lyndon 2015). However, the impacts of frailty and MCI on healthcare and societal costs and on qualityadjusted life years (QUALYs) remains unexplored in KTx. The GERAS study will provide essential evidence for further studies on how frailty and MCI influence KTx costs.

\section{Advancing frailty and MCI research in KTx by examining the conditions' development and aetiology}

While frailty can improve, without intervention, older nonTx patients' frailty commonly worsens (Clegg et al. 2013, Apostolo et al. 2015, Goldraich et al. 2015, Harrison et al. 2015, Musso et al. 2015). Nevertheless, in KTx, the one available study examining frailty changes indicates immediate posttransplant deterioration, with recovery to baseline status or better after 3 months (McAdams-Demarco et al. 2015a). Longitudinal post kidney transplantation cognitive function studies are rare. While two studies have reported net posttransplant improvements, their results have limited applicability to older patients, as both included relatively young patients (Griva et al. 2006, Van Sandwijk et al. 2015). Research with extended follow-up times and across adult KTx recipients of all ages will provide key insights into frailty's pre-Tx to posttransplant development.

Concomitantly, current biological frameworks of frailty aetiology (see 'conceptual frameworks') suggest origins in the dysregulation of the neuroendocrine, musculoskeletal, metabolic and other physiological systems (Fulop et al. 2015). In older non-Tx cohorts, recent longitudinal studies suggest the immune/inflammatory system as a key pathway (Leng et al. 2007, 2009, Li et al. 2011, Collerton et al. 2012, Chen et al. 2014). Complex immune system alterations are hypothesized to cause chronic low-grade systemic inflammation, inducing frailty and increasing susceptibility to chronic conditions, disabilities and mortality (Fulop et al. 2015). Associations between frailty and certain proinflammatory markers - interleukin-6 (IL-6), tumour necrosis factor $\alpha(\mathrm{TNF}-\alpha)$ and C-reactive protein (CRP) and white blood cell count (WBC) - are well-documented (Leng et al. 2007, 2009, Li et al. 2011, Collerton et al. 2012,
Chen et al. 2014, Theou \& Rockwood 2015). Notably, despite emerging aetiological pathways for MCI (Halil et al. 2015), no reliable causal relationship has been established (Gale et al. 2013, Fulop et al. 2015, Theou \& Rockwood 2015). With only one related study in Tx recipients (Singer et al. 2015), inflammation markers' pre-Tx to posttransplant evolution and their interrelationships with frailty and MCI in KTx offer high research potential (De Martinis et al. 2006, Li et al. 2011, Gale et al. 2013, Fulop et al. 2015, Hubbard \& Jatoi 2015).

\section{The study}

\section{Aims}

The GERAS study's primary aims are: (1.1) to examine whether pre-Tx frailty and MCI predict patient's survival and HR-QOL posttransplant (primary outcome) and graft survival and acute rejection episodes (secondary outcomes); (1.2) to explore whether pre-Tx frailty and MCI predict healthcare and societal costs of KTx; and (1.3) to assess and compare posttransplant QUALYs of KTx recipients who are non-frail, pre-frail/frail and pre-frail/frail with MCI. Our initial hypothesis is that pre-Tx frailty and MCI can have a negative impact on these primary and secondary outcomes.

The project's secondary aims are: (2.1) to examine the prevalence, evolution and interrelationships of frailty and MCI for 2 years posttransplant; (2.2) to examine the levels of selected inflammatory biomarkers (CRP, total WBC, TNF- $\alpha$ and IL-6) in relationship with frailty status and MCI; and (2.3) to explore whether pre-Tx levels of the selected biomarkers predict changes in frailty status and cognitive function.

\section{Methodology}

\section{Conceptual frameworks}

The GERAS study employs four conceptual frameworks: (1) The Fried Frailty Phenotype is an internationally applied, psychometrically validated conceptual model of frailty. Based on indicators of physical fitness and metabolism, it measures weakness, slowness, low levels of physical activity, lower total energy expenditure and chronic undernutrition. Depending on the number of indicators present, patients are classed as: non-frail (score 0); pre-frail (score 1-2); or frail (score $\geq 3$ ) (Fried et al. 2001, 2004, Cesari et al. 2014, Walston \& Bandeen-Roche 2015). This is predominantly applied in end-stage organ failure to predict risks of adverse outcomes independent of chronological age, comorbidities and disabilities. Its 10- 
minute administration time suits it to routine clinical application (Exterkate et al. 2016). (2) The STCS-developed Expanded Biopsychosocial Framework for Transplant Research (described by De Geest et al. 2013) provides biopsychosocial perspective to select outcomes and confounders. (3) Chen et al.'s (2014) conceptual model will guide explorations of the interrelationships between frailty and MCI and (4) Halil et al.'s (2015) model highlights chronic low-grade systemic inflammation's aetiological role in both conditions.

\section{Study design, setting}

GERAS is a multi-centre prospective cohort study across five Swiss KTx centres. It is nested in the STCS, a long-term open prospective cohort study that has enrolled over $95 \%$ of KTx recipients in Switzerland since 2008. More information on the STCS is described elsewhere (Koller et al. 2013). Assessing patients immediately pre-Tx, with follow-up at 6 months, 1 and 2 years post-Tx, the GERAS study began in January 2015 and will extend until June 2020. Figure 1 illustrates the study design, data sources and variables.

\section{Study team and cooperation partners}

This study is integrated in a research programme on ageing and frailty in KTx. Coordinated via the University of Basel's Institute of Nursing Science (INS), it represents a collaboration between five Swiss KTx centres, Johns Hopkins University (US), University of Pittsburgh (US) and the University of Lugano (Switzerland). Cooperation partners include the STCS, all participating hospitals' laboratories and management control units, the University Hospital Basel Clinical Trial Unit, Santésuisse and the Swiss Krankenkasse (healthcare fund).

\section{Sample selection and size}

A consecutive recruited convenience sample of adult deceased- and living-donor KTx recipients (aged $\geq 20$ years) who are enrolled in the STCS is included, unless they are multiple organ $\mathrm{Tx}$ recipients, are incapable of informed consent (IC), have insufficient knowledge of English, French, German or Italian, or have severe functional impairments which could influence the cognitive tests. A power analysis for patient and graft survival (aim 1.1) indicated a minimum sample size of 250 patients for detection of proportional differences within reported ranges in both outcomes according to frailty status at $\mathrm{KTx}$ [5-year post-Tx patient survival: $77.5 \%$ for frail vs. $91.5 \%$ for non-frail patients, based on pre-KTx frailty prevalence $(25.1 \%$ frail, $74.9 \%$ non-frail)], with $80 \%$ power and a two-sided alpha level of 0.05 (Garonzik-Wang et al. 2012, McAdams-
Demarco et al. 2015b). Study enrolment began in February 2016 and will continue for approximately 25 months, guided by the yearly number of adult KTx in Switzerland ( $n=296$, data 2014) (SwissTransplant 2014) and $15 \%$ non-eligibility, $15 \%$ non-participation and $30 \%$ attrition.

\section{Data sources, variables and measurements}

Data sources include: (1) STCS datasets; (2) primary patient data collection via established or investigator-developed interview questionnaire (Table 1); and (3) other data sources (medical charts, hospitals' management control records, the Swiss healthcare fund, the Swiss Federal Statistical Office and the European Renal Association).

All GERAS study documents are available in English, French, German and Italian. They were developed via iterative processes with multiple review rounds by researchers. Culturally sensitive professional translations were performed. Thereafter, native-speaking research team members and nursing researchers reviewed translation accuracy, item comprehensibility and data availability at KTx centres. Using a convenience sample of haemodialysis patients, KTx candidates and $\mathrm{KTx}$ recipients, the procedures and instruments were pilot tested in three centres. Variables and measurements are described in detail below.

\section{Primary variables of interest}

Frailty is assessed pre-Tx, at 6 months, 1 year and 2 years posttransplant, using an adapted Fried Frailty Instrument (Table 2; Jha et al. 2016a). Originally developed and psychometrically tested in the US Cardiac Health Study (Fried et al. 2001), then modified for Tx patients, both the original and modified versions have good construct and predictive validity across chronically ill cohorts. In endstage organ failure and $\mathrm{Tx}$, it has predictive validity for biomedical outcomes in middle-aged and older adults (Garonzik-Wang et al. 2012, Hamaker et al. 2012, McAdams-Demarco et al. 2013b, 2015a,b, Lai et al. 2014b, Buta et al. 2015, Handforth et al. 2015, Theou et al. 2015). The modified version requires ten minutes to evaluate five domains: 'weakness' (measured hand grip strength), 'slowness' (measured habitual walking speed), 'a low level of physical activity' (one self-report item), 'a lower total energy expenditure' (one self-report item on subjective exhaustion) and 'chronic undernutrition' (one self-report item on loss of appetite). Given that pre- to posttransplant weight assessments often reflect fluctuating fluid levels, self-reported loss of appetite was used to measure chronic undernutrition. Summary scores indicate non-frailty (score 0), pre-frailty (score 1-2) or frailty (score 3-5) (Table 2) (Jha et al. 2016a). 


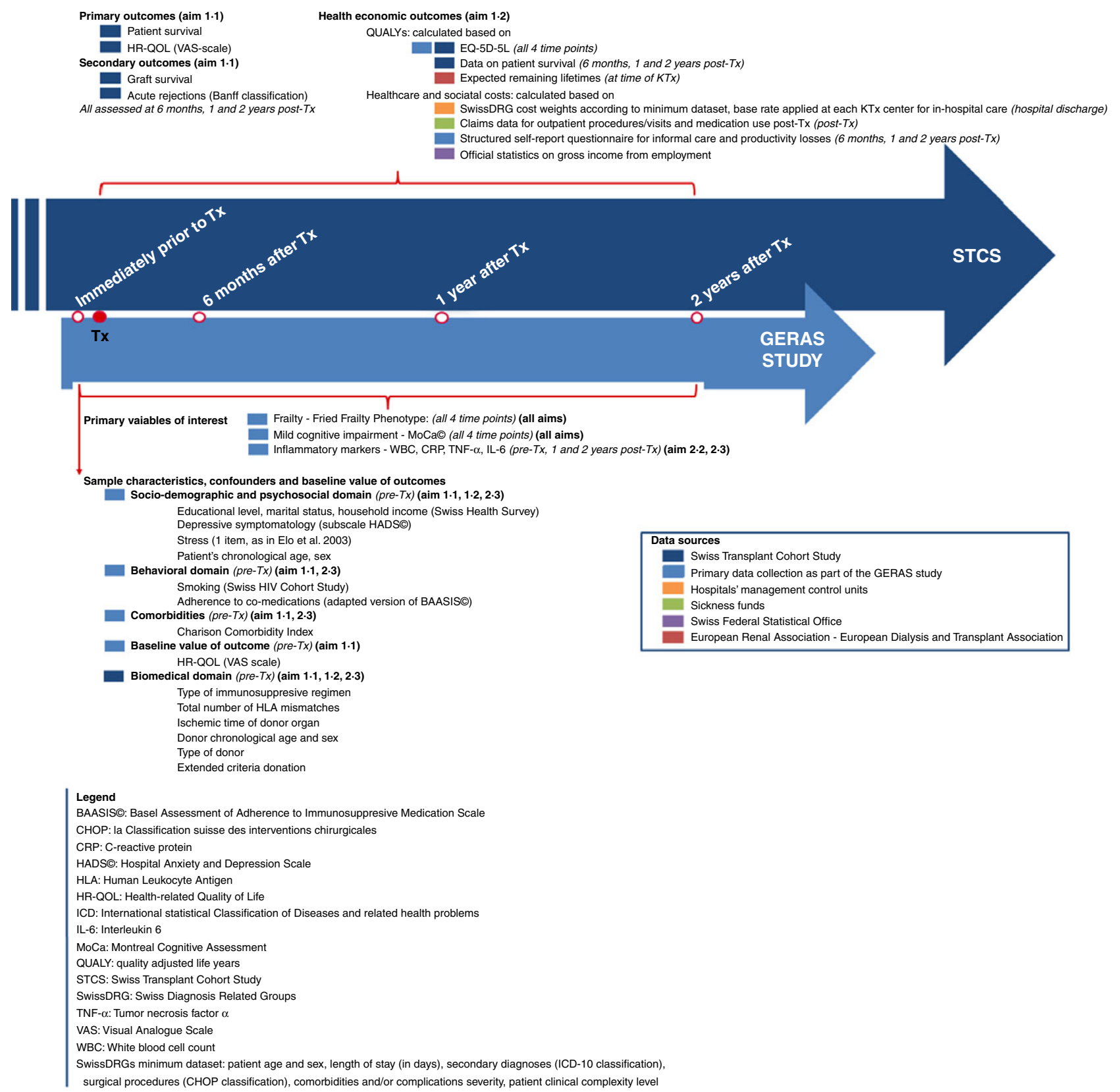

Figure 1 Flow chart of the GERAS study design, data sources and variables.

MCI is assessed via the Montreal Cognitive Assessment (MoCA) pre-Tx, then at 6 months, 1 year and 2 years post-Tx. This 10-minute assessment covers visiospatial and executive functioning, naming, memory, attention, language, abstraction, delayed recall and orientation (Nasreddine et al. 2005, Tiffin-Richards et al. 2014, Apostolo et al. 2015, Cecato et al. 2016, Julayanont et al. 2015). Regarding MCI detection in older community-dwelling adults and haemodialysis patients, the MoCA's sensitivity and specificity exceed those of the Mini Mental State Examination (gold standard). Possible scores range from 0-30; scores
$<26$ indicate MCI. To avoid recall bias for certain items (e.g. general vocabulary, animal names, calculations), a different version is used for each measurement point (Nasreddine et al. 2005, Tiffin-Richards et al. 2014, Julayanont et al. 2015).

Inflammatory biomarkers: total WBC (in $10^{9} / \mathrm{L}$ ) and CRP (in milligrams per litre) are determined for venous blood samples (serum and ethylenediamine tetra-acetic acid sample) pre-Tx, then at 1 and 2 years post-Tx. As levels of TNF- $\alpha$ and IL- 6 are not monitored in the STCS, measurements (in picograms per millilitre) are based on serum 
Table 1 Investigator-developed questionnaire on informal care and productivity losses.

\begin{tabular}{|c|c|c|}
\hline Construct & Instructions and question & Variable type and values \\
\hline General information & $\begin{array}{l}\text { Please fill out this general information before } \\
\text { conducting the interview: } \\
\text { a. Day of the interview } \\
\text { b. Who was interviewed? } \\
\text { c. Who conducted the interview? }\end{array}$ & $\begin{array}{l}\text { a. Open-ended: Day/Month/Year } \\
\text { b. Categorical: The patient / An informal caregiver of the } \\
\text { patient / The patient and caregiver were interviewed } \\
\text { together } \\
\text { c. Open-ended: name and surname }\end{array}$ \\
\hline $\begin{array}{l}\text { Living arrangements } \\
\text { of the patient }\end{array}$ & Where does the patient currently live? & $\begin{array}{l}\text { Categorical: At home alone / At home with other people / } \\
\text { In a healthcare or social organization (please indicate the } \\
\text { name of the organization, and unit/ward - if applicable) } \\
\text { / Other, please specify }\end{array}$ \\
\hline $\begin{array}{l}\text { Changes to the } \\
\text { working condition } \\
\text { of the patient }\end{array}$ & $\begin{array}{l}\text { In the last } 6 \text { months / } 1 \text { year, did the patient have } \\
\text { to change her/his working condition because of } \\
\text { her/his kidney transplantation? }\end{array}$ & $\begin{array}{l}\text { Categorical: No / She/he had to quit her/his job / She/he } \\
\text { had to reduce the frequency of her/his occupation } \\
\text { (please specify the reduction in \%) / She/he lost working } \\
\text { days (please specify how many days) / Other, please } \\
\text { specify: }\end{array}$ \\
\hline Homecare received & $\begin{array}{l}\text { In the last } 6 \text { months / } 1 \text { year, did the patient and/ } \\
\text { or her/his relatives pay for homecare assistance } \\
\text { because of the kidney transplantation? }\end{array}$ & $\begin{array}{l}\text { Table indicating the following types of homecare } \\
\text { assistance: domestic worker / companion / } \\
\text { physiotherapist / nurse / other (please specify). For each, } \\
\text { the interviewer indicates: } \\
\text { a. Open-ended: Frequency with which the homecare } \\
\text { assistance was received } \\
\text { b. Open-ended: Total estimated expenditure by the } \\
\text { patient and/or her/his relatives }\end{array}$ \\
\hline $\begin{array}{l}\text { Presence of and } \\
\text { information on the } \\
\text { patient's informal } \\
\text { caregiver }\end{array}$ & $\begin{array}{l}\text { a. Does the patient have a person who assists her/ } \\
\text { him in daily life, but is not paid for doing so } \\
\text { (informal caregiver)? (Note: if the patient has } \\
\text { more than one informal caregiver, please fill out } \\
\text { this question for the person who assists her/him } \\
\text { most frequently) } \\
\text { b. What is the age of the informal caregiver? } \\
\text { c. What is the sex of the informal caregiver? }\end{array}$ & $\begin{array}{l}\text { a. Dichotomous: Yes / No (please stop the interview) } \\
\text { b. Open-ended: years } \\
\text { c. Dichotomous: Male / Female } \\
\text { d. Categorical: Employed / Student / Housewife or - man } \\
\text { / Retired / Unemployed } \\
\text { e. Categorical: No management function / Top, upper or } \\
\text { middle level management function / Lower management } \\
\text { function / Other (please specify) }\end{array}$ \\
\hline
\end{tabular}

d. What is the working condition of the informal caregiver?

e. If she/he is employed, please specify his/her function

Presence of and information on the patient's informal caregiver (cont.) a. Please specify the highest educational degree completed by the informal caregiver:

b. What is the relationship of the informal caregiver with the patient?
Type of assistance provided by the informal caregiver
In the last 6 months / 1 year, which type(s) of assistance did the informal caregiver provide to the patient, and how much time did she/he dedicate for doing so? a. Categorical: No completed school or professional education (less than 9 formation years) / Mandatory school (primary/secondary/junior high/district school) (9 formation years) / Apprenticeship or full-time vocational school (10-13 formation years) / Diploma qualifying for university admission (Matura) (13 formation years) / Higher professional education (e.g. master craftsman diploma, federal diploma) (14-16 formation years) / Higher technical or commercial school (e.g. school for social work, school for engineering) (14-18 formation years) / University degree (e.g. bachelor or master of science) (16 or more formation years) / Other education (open-ended question) / I do not want to answer

b. Categorical: Spouse or partner / Son or daughter / Other family member (please specify) / Friend / Other (please specify)

Open-ended: table indicating 'type of assistance' and 'number of hours per day' 
Table 1 (Continued).

\begin{tabular}{|c|c|c|}
\hline Construct & Instructions and question & Variable type and values \\
\hline $\begin{array}{l}\text { Changes in the } \\
\text { working condition } \\
\text { of the informal } \\
\text { caregiver }\end{array}$ & $\begin{array}{l}\text { In the last } 6 \text { months / } 1 \text { year, did the informal } \\
\text { caregiver have to change her/his working } \\
\text { condition to assist the patient? }\end{array}$ & $\begin{array}{l}\text { See item 'Changes to the working condition of the } \\
\text { patient' }\end{array}$ \\
\hline $\begin{array}{l}\text { Financial support } \\
\text { for informal } \\
\text { caregiving }\end{array}$ & $\begin{array}{l}\text { Does the informal caregiver receive financial } \\
\text { support for assisting the patient? }\end{array}$ & $\begin{array}{l}\text { Dichotomous: No / Yes (please specify the type and } \\
\text { amount of financial support received) }\end{array}$ \\
\hline $\begin{array}{l}\text { Assistance provided } \\
\text { to the patient by } \\
\text { other people }\end{array}$ & $\begin{array}{l}\text { a. In the last } 6 \text { months / } 1 \text { year, have there been } \\
\text { other people who assisted the patient, although } \\
\text { with less intensity than the caregiver? } \\
\text { b. If yes, please fill out the following table }\end{array}$ & $\begin{array}{l}\text { a. Dichotomous: No / Yes } \\
\text { b. Open-ended: table indicating 'relationship with the } \\
\text { patient' and 'number of hours per week' }\end{array}$ \\
\hline $\begin{array}{l}\text { Transportation } \\
\text { expenditures for } \\
\text { patient assistance } \\
\text { incurred by the } \\
\text { patient or the } \\
\text { caregiver }\end{array}$ & $\begin{array}{l}\text { a. In the last } 6 \text { months / } 1 \text { year, did the patient or } \\
\text { the caregiver bear the burden of transportation } \\
\text { expenditures for patient assistance? } \\
\text { b. If yes, please fill out the following table, } \\
\text { indicating information for a one-way trip (not a } \\
\text { round-trip). }\end{array}$ & $\begin{array}{l}\text { a. Dichotomous: No / Yes } \\
\text { b. Open-ended: table indicating 'distance }(\mathrm{km}) \text { ', } \\
\text { 'transportation means', 'estimated expenditure' and } \\
\text { 'number of times' }\end{array}$ \\
\hline $\begin{array}{l}\text { Other expenditures } \\
\text { for patient } \\
\text { assistance incurred } \\
\text { by the patient or } \\
\text { the caregiver }\end{array}$ & $\begin{array}{l}\text { a. In the last } 6 \text { months / } 1 \text { year, did the patient or } \\
\text { the caregiver bear the burden of other } \\
\text { expenditures for patient assistance? } \\
\text { b. If yes, please fill out the following table, } \\
\text { indicating the type, estimated cost and frequency } \\
\text { of each expenditure. }\end{array}$ & $\begin{array}{l}\text { a. Dichotomous: No / Yes } \\
\text { b. Open-ended: table indicating 'type of expenditure', } \\
\text { 'estimated expenditure' and 'number of times' }\end{array}$ \\
\hline
\end{tabular}

samples collected during the GERAS study. Each KTx centre's laboratory performs pre-analytical procedures according to study-specific standard operating procedures. The University Hospital Basel's Department of Laboratory Medicine coordinates shipping and analysis of the serum samples.

\section{Primary, secondary and health economic outcomes}

Primary outcomes for aim 1.1 are patient survival and HRQOL; secondary outcomes are graft survival and acute rejection episodes. Health economic outcomes for aim 1.2 are QUALYs and health care and societal costs of KTx. Table 3 provides detailed information on all outcomes.

\section{Socio-demographic variables}

Three items are assessed pre-Tx using the STCS Psychosocial Questionnaire: educational level (categorical, nine answer categories), marital status (categorical, four answer options) and household income (categorical, five answer options). As noted above, the STCS self-report questionnaire consists of psychometrically tested items (De Geest et al. 2013, 2014). Patients' chronological age (continuous, in years) and sex (male / female) are retrieved via medical chart review.

\section{Psychological and behavioural variables}

Four psychosocial variables are assessed pre-Tx using the STCS Psychosocial Questionnaire: depressive symptomatology [Hospital Anxiety and Depression Scale-7 item depression subscale (Zigmond, 1983)], stress [categorical, five response options as in occupational research (Elo et al. 2003)], smoking (categorical, five answer options, from the Swiss HIV Cohort Study) and adherence to medications [two items on taking adherence and drug holidays from an adapted version of the Basel Assessment of Adherence to Immunosuppressive Medications Scale (BAASISC)] (Glass et al. 2006, 2008, Deschamps et al. 2008, Ducci et al. 2013, Marsicano Ede et al. 2013).

\section{Biomedical variables}

Five variables are extracted from STCS data: immunosuppressive regimen type (Azathioprine, Cyclosporin, ECMycophenolic acid, Everolimus, Glucocorticoid, Mycophenolat mofetil, Sirolimus, Tacrolimus, induction therapy), total number of HLA mismatches (count), cold ischaemic time of donor organ (minutes), donor and recipient chronological ages (years), donor and recipient sexes (male /female), donor type (post-brain death (DBD), postcirculatory death (DCD), living-related or living-unrelated), extended-criteria donor (yes/no). Information on the STCS data has previously been elaborated (Koller et al. 2013, De Geest et al. 2014). Based on medical chart review at KTx, the total number of comorbidities is assessed via a Charlson 
Table 2 Fried Frailty Instrument as adapted for Tx patients (Fried et al. 2001).

\begin{tabular}{|c|c|}
\hline Domain & Assessment and scoring \\
\hline Weakness & $\begin{array}{l}\text { Assessment: Grip strength as measured by the hand-held Jamar dynamometer (Sammons Preston Inc., } \\
\text { Boiling Brook, IL), which has established test-retest, inter- and intra-rater reliability (Roberts et al. } \\
\text { 2011). } \\
\text { - Standardized assessment protocol from the American Society of Hand Therapy, as adapted by } \\
\text { Roberts et al. (2011). } \\
\text { - Mean values of three consecutive tests of maximum grip strength with the left and right hand are } \\
\text { calculated. Grip strength is considered weak if this mean value is } \leq \text { two standard deviations of } \\
\text { sex- and age-adjusted normative values (Mathiowetz et al. 1985). } \\
\text { - Hand dominance, and the location of a dialysis shunt are recorded. } \\
\text { Scoring: } 1 \text { point if weakness is present. }\end{array}$ \\
\hline Slowness & $\begin{array}{l}\text { Assessment: Time in seconds to complete a } 5 \mathrm{~m} \text { walk at the patient's habitual pace is tested, measured } \\
\text { following a standardized protocol. Walking speed is considered slow if the average of three attempts } \\
\text { takes } \geq 6 \text { seconds. } \\
\text { Scoring: } 1 \text { point if slowness is present. }\end{array}$ \\
\hline Low level of physical activity & $\begin{array}{l}\text { Assessment: through } 1 \text { closed-ended question: 'How often do you engage in activities that require a } \\
\text { low or moderate level of energy, such as gardening, cleaning the car or going for a walk? (Answer } \\
\text { options: more than once a week / once a week / one to three times a month / hardly ever, or never). } \\
\text { A response of 'one to three times a month' or 'hardly ever, or never' is classified as a low level of } \\
\text { physical activity. } \\
\text { Scoring: } 1 \text { point if a low level of physical activity is present. }\end{array}$ \\
\hline Exhaustion & $\begin{array}{l}\text { Assessment: through } 2 \text { closed-ended questions: 'In the last week, did you feel on at least three days, } \\
\text { that everything you did was an effort?' and 'In the last week, did you feel on at least three days, that } \\
\text { you could not get going?' (Answer option for each question: yes / no). A response of 'yes' to either } \\
\text { one or both questions is considered as exhaustion. } \\
\text { Scoring: } 1 \text { point if exhaustion is present. }\end{array}$ \\
\hline Loss of appetite* & $\begin{array}{l}\text { Assessment: through } 1 \text { closed-ended question: 'Have you, in the last three months, been eating more/ } \\
\text { less than usual?' (Answer options: less / unchanged / more). A response of 'less' is classified as } \\
\text { chronic undernutrition. } \\
\text { Scoring: } 1 \text { point if chronic undernutrition is present. }\end{array}$ \\
\hline Overall score & Non-frail: 0, Pre-frail: 1-2, Frail: 3-5 \\
\hline
\end{tabular}

*The adaptation for Tx patients considers the item loss of appetite, which is questioned instead of unintentional weight loss. The latter is unreliable in Tx populations given potential fluid overload.

Comorbidity Index version adapted for KTx (Hemmelgarn et al. 2003). HR-QOL (VAS scale) will be measured pre-Tx to control for its baseline value.

\section{Patient recruitment and data collection}

Coordinated and led by the INS, patient recruitment and data collection involve four phases:

- Training of data collectors, including research team members, KTx centre nursing and medical staff and nursing science students. All are trained in their native language through personalized sessions at KTx centres. Moreover, each receives a step-by-step data collection manual and podcast and can contact GERAS team members if required.

- Patient recruitment: on patients' hospital admission for KTx, data collectors assess their eligibility and fulfil informed consent (IC) requirements for living- and deceased-donor grafts.

- Data collection: data collection packages are prepared at the INS and the coordinating laboratory. Patients' primary data are collected as follows: (1) patient data coding form, (2) Fried Frailty Instrument, (3) MoCA, (4) STCS Psychosocial Questionnaire, (5) venous blood sampling, (6) investigator-developed interview questionnaire on informal care received and productivity losses. Thereafter, the Charlson Comorbidity Index is scored based on medical chart review. Patient data collection booklets are stored in sealed envelopes and blood samples sent to participating laboratories according to centre-specific procedures.

- Return of completed data collection booklets: after storage in locked cabinets at the KTx centres, 
Table 3 Overview of primary, secondary and health economic outcomes.

\begin{tabular}{|c|c|c|}
\hline Outcome & $\begin{array}{l}\text { Variable type and values } \\
\text { Time point(s) }\end{array}$ & Data source, measurement and psychometrics (if applicable) \\
\hline $\begin{array}{l}\text { Patient survival (Primary } \\
\text { outcome) }\end{array}$ & $\begin{array}{l}\text { Dichotomous (yes / no) \& time- } \\
\text { to-event. } \\
6 \text { months, } 1 \text { and } 2 \text { years post-Tx. }\end{array}$ & $\begin{array}{l}\text { STCS dataset: registered by two independent physicians. STCS } \\
\text { Endpoint Committee ascertains registered deaths (Koller et al. } \\
\text { 2013). }\end{array}$ \\
\hline $\begin{array}{l}\text { HR-QOL (Primary } \\
\text { outcome) }\end{array}$ & $\begin{array}{l}\text { Continuous (range } 0-100 \text { ). } \\
6 \text { months, } 1 \text { and } 2 \text { years post-Tx. }\end{array}$ & $\begin{array}{l}\text { STCS dataset: VAS. Psychometric properties in oncology patients } \\
\text { are reported in (de Boer et al. 2004). }\end{array}$ \\
\hline $\begin{array}{l}\text { Graft survival } \\
\text { (Secondary outcome) }\end{array}$ & $\begin{array}{l}\text { Dichotomous (yes / no) \& time- } \\
\text { to-event. } \\
6 \text { months, } 1 \text { and } 2 \text { years post-Tx. }\end{array}$ & $\begin{array}{l}\text { STCS dataset: STCS classification developed by clinical experts } \\
\text { (Koller et al. 2013). }\end{array}$ \\
\hline $\begin{array}{l}\text { Acute rejection (Secondary } \\
\text { outcome) }\end{array}$ & $\begin{array}{l}\text { Dichotomous (yes / no). } \\
6 \text { months, } 1 \text { and } 2 \text { years post-Tx. }\end{array}$ & $\begin{array}{l}\text { STCS dataset: measured according to the Banff classification system } \\
\text { (Wu et al. 2014, Wu et al. 2015). }\end{array}$ \\
\hline $\begin{array}{l}\text { Healthcare and societal } \\
\text { costs (Health economic } \\
\text { outcome) }\end{array}$ & $\begin{array}{l}\text { Continuous, dichotomous \& } \\
\text { categorical. } \\
\text { Pre-Tx, data reflecting time of } \\
\text { hospital discharge, at } 6 \text { months, } \\
1 \text { and } 2 \text { years post-Tx. }\end{array}$ & $\begin{array}{l}\text { Calculated based on: } \\
\text { - Management control unit of KTx centres: SwissDRG cost } \\
\text { weights associated to each patient case (in-hospital care) based } \\
\text { on minimum dataset; base rate applied in each KTx centre } \\
\text { (SwissDRG AG 2016). } \\
\text { - Sickness funds [recruited through Santésuisse (Santésuisse, } \\
\text { 2016)]: claims data for each outpatient procedure/visit per- } \\
\text { formed or medication used (posttransplant). } \\
\text { - Structured self-report questionnaire filled out by patients and/or } \\
\text { their primary informal caregiver: informal care and productiv- } \\
\text { ity losses (see table 6). } \\
\text { - Swiss Federal Statistical Office: Official statistics on gross } \\
\text { income from employment to calculate cost of time (Swiss Fed- } \\
\text { eral Statistical Office 2014). }\end{array}$ \\
\hline $\begin{array}{l}\text { Quality-adjusted life years } \\
\text { (QUALYs) (Health } \\
\text { economic outcome) }\end{array}$ & $\begin{array}{l}\text { Categorical, } 5 \text {-point Likert scale. } \\
\text { Pre-Tx, at } 6 \text { months, } 1 \text { and } \\
2 \text { years post-Tx. } \\
\text { Dichotomous (yes / no) \& time- } \\
\text { to-event. } \\
6 \text { months, } 1 \text { and } 2 \text { years post-Tx. } \\
\text { Continuous. } \\
\text { At time of Tx. }\end{array}$ & $\begin{array}{l}\text { Calculated based on: } \\
\text { - Primary data collection with STCS Psychosocial questionnaire } \\
\text { (pre-Tx, see 2.3.3.3); STCS dataset (posttransplant): EuroQol- } \\
\text { 5D-5L instrument (Drummond et al. 2015, EuroQol 2016). } \\
\text { - STCS dataset: data on patient survival (see supra). } \\
\text { - European Renal Association - European Dialysis and Trans- } \\
\text { plant Association Registry: Annual Report for expected remain- } \\
\text { ing lifetimes at time of KTx [European Renal Association - } \\
\text { European Dialysis and Transplant Association (ERA-EDTA), } \\
\text { 2013]. }\end{array}$ \\
\hline
\end{tabular}

KTx, kidney transplantation; Pre-Tx, pre-transplant; Post-Tx, post-transplant; STCS, Swiss Transplant Cohort Study; SwissDRG, Swiss Diagnosis Related Groups; Tx, transplantation; VAS, Visual Analogue Scale.

completed booklets are collected bi-monthly by research team members and confidentially stored at the INS data management centre. Prior to analysis, data quality (e.g. completeness) is verified.

\section{Data management and analysis}

In collaboration with the University Hospital Basel Clinical Trial Unit, a secure web-based data platform (SecuTrial ${ }^{\circledR}$ ) is used to ensure comprehensive structured patient followup and to enter, manage, link and code data from all sources (SecuTrial, 2000). Initially, missing data, data distributions and violations of assumptions underlying applied statistical techniques are checked and handled as appropriate. All analyses employ STATA (StataCorp LP, College Station, TX, USA) and SAS (SAS Institute AG, Wallisellen, Switzerland) statistical software, applying a twotailed significance level $(\alpha)$ of .05. Data analyses are performed as follows:

Aim 1.1: Patient survival (primary outcome) and graft survival (secondary outcome) require a competing risks analysis to account for simultaneous risks of mortality and graft loss in KTx (Pintilie 2007, Bakoyannis \& Touloumi 2012, Koller et al. 2012, Wolbers et al. 2014, Geskus 2015). Standard analysis for this type of data results in overestimated outcome probabilities (Bakoyannis \& Touloumi 2012, Wolbers et al. 2014, Fonseca et al. 2015, Geskus 2015). For both outcomes the cause-specific hazard 
(CSH) and cumulative incidence functions (CIF) are displayed and a multivariate regression performed. Using frailty and MCI as independent variables of interest, sociodemographic, biomedical, psychosocial and behavioural variables are screened as potential confounders. Regression on the CSH consists of a Cox cause-specific proportional hazards model, regression on the CIF of a Fine and Gray model (Lee et al. 2012, Wolbers et al. 2014, Geskus 2015).

Aim 1.2: Regarding HR-QOL (primary outcome) and acute rejection episodes (secondary outcome), multivariate mixed effects logistic and linear regression models are applied to flexibly account for the multi-level clustered longitudinal data structure and missing data. In all models, patients are added as a random effect, with length of follow-up, frailty and MCI considered as fixed effects. Sociodemographic, biomedical, psychosocial and behavioural variables are tested as confounders. The necessity of including polynomials to model a non-linear relationship with HR-QOL is explored. In all models for aim 1.1, interaction between frailty and MCI is tested to explore a potential cumulative effect on outcomes. Also, the use of variable- or patient-clustering techniques is explored to summarize information on correlated variables. Model building applies a block-entry method.

Aim 1.3: For health economic outcomes, a discount rate of $3 \%$ is applied to both costs and QUALYs (Gold et al. 1996, Tan-Torres Edejer et al. 2003). Up to 2 years posttransplant, health care and societal costs and QUALYs are described via appropriate descriptive measures of central tendency and dispersion. Comparison of healthcare and societal costs, and QUALYs are performed for the three clinically relevant subgroups: non-frail vs. pre-frail/frail vs. pre-frail/frail with MCI. Graphic representations are applied for data visualization. A mixed effects log-linear regression model is applied for the continuous outcome variable of healthcare and societal costs, where patients are added as a random effect. Follow-up length, frailty, MCI and the interaction of the latter two conditions are considered fixed effects. Socio-demographic, biomedical and psychosocial variables are tested as confounders.

Aim 2.1: Prevalence, evolution and interrelationships between frailty and MCI are analysed descriptively from pre-Tx to 2 years posttransplant. Graphic methods are applied for data visualization. Changes over time are tested using mixed effects regression modelling, with frailty and MCI employed as mutual predictors to test for interrelationships between the two.

Aim 2.2: Descriptive statistics of central tendency and variability are applied to describe the levels of the selected inflammation markers (CRP, total WBC, TNF- $\alpha$ and IL-6) in relation to frailty status (non-frail, pre-frail or frail) and cognitive function (MCI, no MCI). Graphics are applied for data visualization. Associations between inflammatory markers, frailty and MCI are tested using a mixed effects (ordinal) logistic regression analysis, with frailty status (non-frail, pre-frail, frail) and MCI (yes/no) as outcome variables. Since inflammatory markers may be correlated, we explore the use of variable- or patient-clustering techniques.

Aim 2.3: The aetiological values of pre-Tx inflammatory markers regarding post-Tx changes in frailty status (nonfrail, pre-frail, frail) are examined using mixed effects logistic regression models, entering patients as a random effect and follow-up time and inflammatory markers as fixed effects. To explore possible delayed effects of inflammatory marker information on frailty, we lag frailty status. Confounders and model building techniques are similar to those used for aim 1.1's mixed-effects models.

Regarding handling of missing data and sensitivity analyses, for all analyses, missing data's biasing effects are mapped and their influence on the modelling results explored using sensitivity analyses under various scenarios. For example, health economic evaluation (aim 1.2), sensitivity analyses use varying discount rates $(0.0 \%, 5.0 \%$ and 6.0\%) (Gold et al. 1996, Tan-Torres Edejer et al. 2003).

\section{Ethical considerations}

The STCS received ethical approval prior to data collection; its IC includes approval for further use of data in STCS approved studies such as this (De Geest et al. 2013, Koller et al. 2013). The GERAS study received ethical approval from all responsible ethical committees (Ref. Nr. EKNZ 2015-235). Participants will be provided with verbal and written information about the study. A written informed consent is obtained prior to participating in the study. Participation is voluntary and may be discontinued at any time without implications for patient treatment. We comply with all national and international guidelines and privacy laws concerning treatment of patients in clinical studies.

\section{The GERAS study consortium}

Patient and provider involvement is organized through an advisory body. Active partnerships are pursued between the research team, KTx patients, the Swiss Kidney Patient Association, KTx nursing, medical and allied health professionals, regional and national governing bodies and policy makers. Integrating these members' diverse perspectives will improve the study's quality, relevance and effectiveness 
regarding researcher conduct and management, analysis, interpretation and dissemination of findings and monitoring and evaluation of the study process. Patient and provider involvement is also essential for successful implementation of our findings in KTx clinical practice and policy development and identification and prioritization of areas for further research (Involve Network and National Institute for Health Research, 2012, National Institute for Health Research and Research Design Service London, 2013).

\section{Validity and reliability/Rigour}

Several steps ensure the GERAS study's validity, reliability and rigour. Nesting the study in the rigourous longitudinal STCS data structure and the application of SecuTrial ${ }^{\circledR}$ for patient follow-up minimizes study drop-out and ultimate selection bias. Across all KTx centres, consistent use of methodologies proven in US and Australian studies on frailty and MCI (Jha et al. 2015, 2016a) ensures national and international comparability of results. Furthermore, all instruments have been tested for reliability and validity in previous studies including Tx populations. When the entire data collection procedure was pre-tested at three participating KTx centres, only minor adaptations were necessary. To check data quality, $5 \%$ of data booklets will be randomly tested, that is, two research team members will independently enter their contents for analysis.

\section{Discussion}

\section{Clinical, scientific and policy impact}

Accumulating evidence on the high prevalence and independent predictive values of frailty and MCI regarding inferior clinical outcomes features both as critical issues for solid organ Tx candidates and recipients. Only recently recognized in Tx, neither condition is fully considered in guidelines for Tx policy, patient assessment nor direct practice pathways. For the rapidly growing group of older $\mathrm{Tx}$ patients, GERAS findings on frailty and MCI will likely guide and optimize clinical management. This is particularly relevant in Swiss settings, where no upper age limit is applied to $\mathrm{Tx}$ candidacy. As the largest solid organ $\mathrm{Tx}$ group, KTx patients receive approximately 296 grafts in Switzerland yearly, each costing Swiss society between 60,000-100,000 Swiss Francs (Federal Office of Public Health, 2012). Thus, the GERAS study is addressing a significant challenge. Moving beyond previous biomedicalfocused frailty research, it jointly examines frailty and MCI from bio-psychosocial and health economic perspectives. This study will continue to drive improvements in care quality and appropriateness and of policy development for ageing and frail KTx cohort as follows:

- Through its comprehensive perspective, the GERAS study will significantly enhance risk prediction regarding adverse outcomes in KTx. Integrating its findings in clinical practice guidelines and training programs will guide modifications in the complex care of pre-frail and frail patients. In addition to enhancing therapeutic decision-making concerning transplant candidacy, it may even accelerate and improve posttransplant rehabilitation and related outcomes (e.g. via enhanced physical therapy, exercise and nutrition). As such an approach is patient-centred, nurses will be key participants, helping optimize chronic illness and symptom management while providing evidence-based psychosocial support.

- Nested in the STCS, studying a nationally representative cohort of KTx patients including older recipients, GERAS enables rigourous study of the clinical, psychosocial and health economic consequences of kidney $T x$ in frail and/or cognitively impaired patients.

- Given the expansion of Tx eligibility to older and more vulnerable patients, it is imperative to understand the impact of frailty and MCI on KTx's cost-effectiveness. Considering patient, healthcare system and societal perspectives, GERAS will identify the risks of transplanting frail and/or MCI patients. At the policy level, it will provide essential evidence about the optimal use of limited resources to maximize health outcomes in adults with ESRD.

- Investigating inflammatory biomarkers in KTx will provide preliminary insights into the relevance of chronic low-grade systemic inflammation as a pathway to frailty and MCI. By exploring these biomarkers' values, GERAS will notably contribute to scientific advancements in pre-KTx screening for frailty and MCI. Supporting diagnosis of both will facilitate tracking their development and assist healthcare professionals in clinical and therapeutic decision-making.

\section{Strengths and limitations}

The GERAS project has three key strengths. First, its multicentre design and nationally representative cohort considerably expand current evidence on frailty and $\mathrm{MCI}$ in $\mathrm{KTx}$, with generalizable results. Second, by jointly examining frailty and MCI from a comprehensive bio-psychosocial 
and health economic perspective, it significantly broadens the existing-primarily clinical-research focus. Third, competing risks analysis is a pioneering methodology: despite the frequent occurrence of competing outcomes, the use of this statistical technique in Tx is still in its infancy (Huang et al. 2014, Aubert et al. 2015, Fonseca et al. 2015, SapirPichhadze et al. 2016).

Conversely, certain limitations should be considered when interpreting our findings. Balanced against our power analysis's required sample size, the rather small number of KTx performed annually in Switzerland precludes a randomized sampling strategy to enhance generalization. Finally, Switzerland's small population, linguistic diversity, variability across care systems and KTx centres and heterogeneous clinical profiles of $\mathrm{KTx}$ donors and recipients might diffuse the impact of frailty and MCI on outcomes.

\section{Acknowledgements}

We wholeheartedly thank and express our gratitude to all persons and institutions for providing invaluable support in preparing and conducting this multi-centre nationwide study: five Swiss kidney transplant centres, all kidney transplant recipients who consent to participate in our study; the data collectors; the funding agencies; the STCS Scientific Board and Executive Office; the Clinical Trial Unit of the University Hospital Basel; the laboratories at all participating hospitals; the professional translators of our study documents; statistical support; colleagues and family members

\section{Funding}

The GERAS study was funded by a research grant of the Swiss Transplant Cohort Study (STCS) in 2015 (FUP073). The STCS provided this funding based on a grant from the Swiss National Research Foundation (grant number 148512); Astellas CH-Europe (unrestricted research grant); Roche CH (unrestricted research grant); Novartis CH (unrestricted research grant).

\section{Conflict of interest}

No conflict of interest has been declared by the author(s).

\section{Author contributions}

All authors have agreed on the final version of the paper and meet at least one of the following criteria [recommended by the International Committee of Medical Journal Editors (ICMJE) (http://www.icmje.org/ethical_1author.html)]:

- substantial contributions to conception and design, acquisition of data or analysis and interpretation of data.

- drafting the article or revising it critically for important intellectual content.

\section{References}

Abecassis M., Bridges N.D., Clancy C.J., Dew M.A., Eldadah B., Englesbe M.J., Flessner M.F., Frank J.C., Friedewald J., Gill J., Gries C., Halter J.B., Hartmann E.L., Hazzard W.R., Horne F.M., Hosenpud J., Jacobson P., Kasiske B.L., Lake J., Loomba R., Malani P.N., Moore T.M., Murray A., Nguyen M.H., Powe N.R., Reese P.P., Reynolds H., Samaniego M.D., Schmader K.E., Segev D.L., Shah A.S., Singer L.G., Sosa J.A., Stewart Z.A., Tan J.C., Williams W.W., Zaas D.W. \& High K.P. (2012) Solid-organ transplantation in older adults: current status and future research. American Journal of Transplantation 12, 26082622.

Apostolo J., Holland C., O’Connell M.D., Feeney J., TabaresSeisdedos R., Tadros G., Campos E., Santos N., Robertson D.A., Marcucci M., Varela-Nieto I., Crespo-Facorro B., Vieta E., Navarro-Pardo E., Selva-Vera G., Balanza-Martinez V. \& Cano A. (2015) Mild cognitive decline. A position statement of the Cognitive Decline Group of the European Innovation Partnership for Active and Healthy Ageing (EIPAHA). Maturitas, 83, 83-93.

Aubert O., Kamar N., Vernerey D., Viglietti D., Martinez F., Duong-Van-Huyen J.P., Eladari D., Empana J.P., Rabant M., Verine J., Rostaing L., Congy N., Guilbeau-Frugier C., Mourad G., Garrigue V., Morelon E., Giral M., Kessler M., Ladriere M., Delahousse M., Glotz D., Legendre C., Jouven X., Lefaucheur C. \& Loupy A. (2015) Long term outcomes of transplantation using kidneys from expanded criteria donors: prospective, population based cohort study. BMJ 351, h3557.

Auyeung T.W., Lee J.S., Kwok T. \& Woo J. (2011) Physical frailty predicts future cognitive decline - a four-year prospective study in 2737 cognitively normal older adults. Journal of Nutrition, Health, and Aging 15, 690-694.

Bakoyannis G. \& Touloumi G. (2012) Practical methods for competing risks data: a review. Statistical Methods in Medical Research 21, 257-272.

de Boer A.G., van Lanschot J.J., Stalmeier P., van Sandick J.W., Hulscher J.B., de Haes J.C. \& Sprangers M.A. (2004) Is a singleitem visual analogue scale as valid, reliable and responsive as multi-item scales in measuring quality of life? Quality of Life Research 13(2), 311-320.

Buta B.J., Walston J.D., Godino J.G., Park M., Kalyani R.R., Xue Q.L., Bandeen-Roche K. \& Varadhan R. (2015) Frailty assessment instruments: systematic characterization of the uses and contexts of highly-cited instruments. Ageing Research Reviews 26, 53-61.

Cano C., Samper-Ternent R., Al Snih S., Markides K. \& Ottenbacher K.J. (2012) Frailty and cognitive impairment as 
predictors of mortality in older Mexican Americans. Journal of Nutrition, Health, and Aging 16 142-147.

Cecato J.F., Martinelli J.E., Izbicki R., Yassuda M.S. \& Aprahamian I. (2016) A subtest analysis of the Montreal cognitive assessment (MoCA): which subtests can best discriminate between healthy controls, mild cognitive impairment and Alzheimer's disease? International Psychogeriatrics 28, 825-832.

Cesari M., Gambassi G., Van Kan G.A. \& Vellas B. (2014) The frailty phenotype and the frailty index: different instruments for different purposes. Age and Ageing 43, 10-12.

Chen X., Mao G. \& Leng S.X. (2014) Frailty syndrome: an overview. Clinical Interventions in Aging 9, 433-441.

Clegg A., Young J., Iliffe S., Rikkert M.O. \& Rockwood K. (2013) Frailty in elderly people. Lancet $381,752-762$.

Collerton J., Martin-Ruiz C., Davies K., Hilkens C.M., Isaacs J., Kolenda C., Parker C., Dunn M., Catt M., Jagger C., Von Zglinicki T. \& Kirkwood T.B. (2012) Frailty and the role of inflammation, immunosenescence and cellular ageing in the very old: cross-sectional findings from the Newcastle $85+$ Study. Mechanisms of Ageing and Development 133, 456-466.

Comans T.A., Peel N.M., Hubbard R.E., Mulligan A.D., Gray L.C. \& Scuffham P.A. (2016) The increase in healthcare costs associated with frailty in older people discharged to a post-acute transition care program. Age and Ageing 45, 317-320.

Danon-Hersch N., Rodondi N., Spagnoli J. \& Santos-Eggimann B. (2012) Prefrailty and chronic morbidity in the youngest old: an insight from the Lausanne cohort Lc65 . Journal of the American Geriatrics Society 60, 1687-1694.

De Geest S., Burkhalter H., Berben L., Bogert L.J., Denhaerynck K., Glass T.R., Goetzmann L., Kirsch M., Kiss A., Koller M.T., Piot-Ziegler C. \& Schmidt-Trucksass A. (2013) The Swiss Transplant Cohort Study's framework for assessing lifelong psychosocial factors in solid-organ transplants. Progress in Transplantation 23, 235-246.

De Geest S., Burkhalter H., Bogert L., Berben L., Glass T.R. \& Denhaerynck K. (2014) Describing the evolution of medication nonadherence from pretransplant until 3 years post-transplant and determining pretransplant medication nonadherence as risk factor for post-transplant nonadherence to immunosuppressives: the Swiss Transplant Cohort Study. Transplant International 27, 657-666.

De Martinis M., Franceschi C., Monti D. \& Ginaldi L. (2006) Inflammation markers predicting frailty and mortality in the elderly. Experimental and Molecular Pathology 80, 219-227.

Denhaerynck K., Dobbels F., Cleemput I., Desmyttere A., SchaferKeller P., Schaub S. \& De Geest S. (2005) Prevalence, consequences and determinants of nonadherence in adult renal transplant patients: a literature review. Transplant International $18,1121-1133$.

Derck J.E., Thelen A.E., Cron D.C., Friedman J.F., Gerebics A.D., Englesbe M.J. \& Sonnenday C.J. (2015) Quality of life in liver transplant candidates: frailty is a better indicator than severity of liver disease. Transplantation 99, 340-344.

Deschamps A.E., De Geest S., Vandamme A.M., Bobbaers H., Peetermans W.E. \& Van Wijngaerden E. (2008) Diagnostic value of different adherence measures using electronic monitoring and virologic failure as reference standards. AIDS Patient Care and STDS 22, 735-743.
Dixon B.S., Vanburen J.M., Rodrigue J.R., Lockridge R.S., Lindsay R., Chan C., Rocco M.V., Oleson J.J., Beglinger L., Duff K., Paulsen J.S. \& Stokes J.B. (2016) Cognitive changes associated with switching to frequent nocturnal hemodialysis or renal transplantation. BMC Nephrology 17, 12.

Dobbels F., Skeans M.A., Snyder J.J., Tuomari A.V., Maclean J.R. \& Kasiske B.L. (2008) Depressive disorder in renal transplantation: an analysis of Medicare claims. American Journal of Kidney Diseases 51, 819-828.

Drame M., Novella J.L., Jolly D., Laniece I., Somme D., Heitz D., Gauvain J.B., Voisin T., De Wazieres B., Gonthier R., Jeandel C., Couturier P., Saint-Jean O., Ankri J., Blanchard F. \& Lang P.O. (2011) Rapid cognitive decline, one-year institutional admission and one-year mortality: analysis of the ability to predict and inter-tool agreement of four validated clinical frailty indexes in the SAFEs cohort. Journal of Nutrition, Health, and Aging 15, 699-705.

Drummond M.F., Sculpher M.J., Clazton K., Stoddart G.L. \& Torrance G.W. (2015) Methods for the Economic Evaluatio of Helath Care Programmes, 4th ed, Oxford University Press, New York.

Ducci J., De Simone P., Denhaerynck K., Dobbels F. \& De Geest S. (2013) Clinical consequences of subclinical non adherence to immunosuppression after liver transplantation. Transplant International, 26, 146.

Dunlay S.M., Park S.J., Joyce L.D., Daly R.C., Stulak J.M., McNallan S.M., Roger V.L. \& Kushwaha S.S. (2014) Frailty and outcomes after implantation of left ventricular assist device as destination therapy. Journal of Heart and Lung Transplantation 33, 359-365.

Elo A.L., Leppanen A. \& Jahkola A. (2003) Validity of a singleitem measure of stress symptoms. Scandinavian Journal of Work, Environment \& Health 29, 444-451.

European Renal Association - European Dialysis and Transplant Association (ERA-EDTA) (2013) Annual Reports [Online]. Retrieved from http://www.era-edta-reg.org/index.jsp? $\mathrm{p}=14$ on 31 January 2016.

EuroQol (2016) EQ-5D-5L Self-complete version on paper. [online] Retrieved from http://www.euroqol.org/eq-5d-products/eq-5d5l.html on 12 May 2016.

Exterkate L., Slegtenhorst B.R., Seyda M., Schuitenmaker J.M., Quante M., Uehara H., El Khal A. \& Tullius S.G. (2016) Frailty and Transplantation. Transplantation 100, 727-733.

Federal Office of Public Health (2012) Costs of Transplantation Medicine [Online]. Retrieved from http://www.bag.admin.ch/ transplantation/00692/02582/03136/index.html?lang=de on May 2016.

Ferguson T.W., Tangri N., Rigatto C. \& Komenda P. (2015) Costeffective treatment modalities for reducing morbidity associated with chronic kidney disease. Expert Review of Pharmacoeconomics and Outcomes Research 15, 243-252.

Flint K.M., Matlock D.D., Lindenfeld J. \& Allen L.A. (2012) Frailty and the selection of patients for destination therapy left ventricular assist device. Circulation: Heart Failure 5, 286293.

Fonseca I., Teixeira L., Malheiro J., Martins L.S., Dias L., Castro Henriques A. \& Mendonca D. (2015) The effect of delayed graft function on graft and patient survival in kidney transplantation: 
an approach using competing events analysis. Transplant International 28, 738-750.

Fried L.P., Tangen C.M., Walston J., Newman A.B., Hirsch C., Gottdiener J., Seeman T., Tracy R., Kop W.J., Burke G. \& McBurnie M.A. (2001) Frailty in older adults: evidence for a phenotype. Journals of Gerontology. Series A, Biological Sciences and Medical Sciences 56, M146-M156.

Fried L.P., Ferrucci L., Darer J., Williamson J.D. \& Anderson G. (2004) Untangling the concepts of disability, frailty and comorbidity: implications for improved targeting and care. Journals of Gerontology. Series A, Biological Sciences and Medical Sciences 59, 255-263.

Fulop T., McElhaney J., Pawelec G., Cohen A.A., Morais J.A., Dupuis G., Baehl S., Camous X., Witkowski J.M. \& Larbi A. (2015) Frailty, inflammation and immunosenescence. In Frailty in Aging: Biological, Clinical and Social Implications (Theou O. \& Rockwood K., eds), Karger Libri, Basel, pp. 26-40.

Gale C.R., Baylis D., Cooper C. \& Sayer A.A. (2013) Inflammatory markers and incident frailty in men and women: the English Longitudinal Study of Ageing. Age (Dordrecht, Netherlands) 35, 2493-2501.

Garg J., Karim M., Tang H., Sandhu G.S., Desilva R., Rodrigue J.R., Pavlakis M., Hanto D.W., Baird B.C. \& GoldfarbRumyantzev A.S. (2012) Social adaptability index predicts kidney transplant outcome: a single-center retrospective analysis. Nephrology, Dialysis, Transplantation 27, 1239-1245.

Garonzik-Wang J.M., Govindan P., Grinnan J.W., Liu M., Ali H.M., Chakraborty A., Jain V., Ros R.L., James N.T., Kucirka L.M., Hall E.C., Berger J.C., Montgomery R.A., Desai N.M., Dagher N.N., Sonnenday C.J., Englesbe M.J., Makary M.A., Walston J.D. \& Segev D.L. (2012) Frailty and delayed graft function in kidney transplant recipients. Archives of Surgery 147, 190-193.

Geskus R.B. (2015) Data Analysis with Competing Risks and Intermediate States. Chapman \& Hall, London.

Glass T.R., De Geest S., Weber R., Vernazza P.L., Rickenbach M., Furrer H., Bernasconi E., Cavassini M., Hirschel B., Battegay M. \& Bucher H.C. (2006) Correlates of self-reported nonadherence to antiretroviral therapy in HIV-infected patients: the Swiss HIV Cohort Study. Journal of Acquired Immune Deficiency Syndromes 41, 385-392.

Glass T.R., De Geest S., Hirschel B., Battegay M., Furrer H., Covassini M., Vernazza P.L., Bernasconi E., Rickenboch M., Weber R. \& Bucher H.C. (2008) Self-reported non-adherence to antiretroviral therapy repeatedly assessed by two questions predicts treatment failure in virologically suppressed patients. Antiviral Therapy 13, 77-85.

Gold M.R., Siegel J.E., Russel L.B. \& Weinstein M.C. (1996). Cost-Effectivenesss in Health ande Medicine. Oxford University Press, New York.

Goldraich L., Alba A., Foroutan F., Maciver J. \& Ross H. (2015). Frailty Phenotype is associated with decreased surival as predicted by the Seattle Heart Failure Model in heart failure patients referred for advanced therapies. Poster presentation, Annual Meeting International Society for Heart and Lung Transplantation. Canadian Journal of Cardiology 31, S107-S108.

Goldstein D.R. (2012) The graying of organ transplantation. American Journal of Transplantation 12, 2569-2570.
Gordon E.J., Prohaska T.R., Gallant M.P., Sehgal A.R., Strogatz D., Yucel R., Conti D. \& Siminoff L.A. (2009) Longitudinal analysis of physical activity, fluid intake and graft function among kidney transplant recipients. Transplant International 22, 990-998.

Griva K., Thompson D., Jayasena D., Davenport A., Harrison M. \& Newman S.P. (2006) Cognitive functioning pre- to postkidney transplantation-a prospective study. Nephrology, Dialysis, Transplantation 21, 3275-3282.

Halil M., Cemal Kizilarslanoglu M., Emin Kuyumcu M., Yesil Y. \& Cruz Jentoft A.J. (2015) Cognitive aspects of frailty: mechanisms behind the link between frailty and cognitive impairment. Journal of Nutrition, Health, and Aging 19, 276283.

Hamaker M.E., Jonker J.M., De Rooij S.E., Vos A.G., Smorenburg C.H. \& Van Munster B.C. (2012) Frailty screening methods for predicting outcome of a comprehensive geriatric assessment in elderly patients with cancer: a systematic review. The Lancet. Oncology 13, e437-e444.

Handforth C., Clegg A., Young C., Simpkins S., Seymour M.T., Selby P.J. \& Young J. (2015) The prevalence and outcomes of frailty in older cancer patients: a systematic review. Annals of Oncology 26, 1091-1101.

Harrison J.K., Clegg A., Conroy S.P. \& Young J. (2015) Managing frailty as a long-term condition. Age and Ageing 44, 732-735.

Hemmelgarn B.R., Manns B.J., Quan H. \& Ghali W.A. (2003) Adapting the Charlson Comorbidity Index for use in patients with ESRD. American Journal of Kidney Diseases 42, 125132.

Huang E., Shye M., Elashoff D., Mehrnia A. \& Bunnapradist S. (2014) Incidence of conversion to active waitlist status among temporarily inactive obese renal transplant candidates. Transplantation 98, 177-186.

Hubbard J.M. \& Jatoi A. (2015) Incorporating biomarkers of frailty and senescence in cancer therapeutic trials. Journals of Gerontology. Series A, Biological Sciences and Medical Sciences 70, 722-728.

Ilinca S. \& Calciolari S. (2015) The patterns of health care utilization by elderly Europeans: frailty and its implications for health systems. Health Services Research 50, 305-320.

Involve Network \& National Institute For Health Research (2012) Briefing Notes for Researchers: Public Involvement in NHS, Public Health and Social Care Research. Retrieved from www.involve.nihr.ac.uk/resource-centre/publications-by-involve on 14 May 2016.

Jacobs J.M., Cohen A., Ein-Mor E., Maaravi Y. \& Stessman J. (2011) Frailty, cognitive impairment and mortality among the oldest old. Journal of Nutrition, Health, and Aging 15, 678-682.

Jha S.R., Ha H.S., Hickman L.D., Hannu M., Davidson P.M., Macdonald P.S. \& Newton P.J. (2015) Frailty in advanced heart failure: a systematic review. Heart Failure Reviews 20, 553-560.

Jha S.R., Hannu M.K., Chang S., Montgomery E., Harkess M., Wilhelm K., Hayward C.S., Jabbour A., Spratt P.M., Newton P., Davidson P.M. \& Macdonald P.S. (2016a) The Prevalence and Prognostic Significance of Frailty in Patients With Advanced Heart Failure Referred for Heart Transplantation. Transplantation 100, 429-436. 
Jha S.R., Hannu M.K., Gore K., Chang S., Newton P., Wilhelm K., Hayward C.S., Jabbour A., Kotlyar E., Keogh A., Dhital K., Granger E., Jansz P., Spratt P.M., Montgomery E., Harkess M., Tunicliff P., Davidson P.M. \& Macdonald P.S. (2016b) Cognitive impairment improves the predictive validity of physical frailty for mortality in patients with advanced heart failure referred for heart transplantation. The Journal of heart and lung transplantation: the official publication of the International Society for Heart Transplantation 35(9), 1092-1100.

Johansen K.L., Delgado C., Bao Y. \& Kurella Tamura M. (2013) Frailty and dialysis initiation. Seminars in Dialysis 26, 690-696.

Julayanont P., Tangwongchai S., Hemrungrojn S., Tunvirachaisakul C., Phanthumchinda K., Hongsawat J., Suwichanarakul P., Thanasirorat S. \& Nasreddine Z.S. (2015) The montreal cognitive assessment-basic: a screening tool for mild cognitive impairment in illiterate and low-educated elderly adults. Journal of the American Geriatrics Society 63, 25502554.

Kelaiditi E., Cesari M., Canevelli M., Van Kan G.A., Ousset P.J., Gillette-Guyonnet S., Ritz P., Duveau F., Soto M.E., Provencher V., Nourhashemi F., Salva A., Robert P., Rieu S., Rolland Y., Touchon J., Fitten J.L. \& Vellas B. \& IANA/IAGG (2013). Cognitive frailty: rational and definition from an (I.A.N.A./ I.A.G.G.) international consensus group. Journal of Nutrition, Health, and Aging, 17, 726-734.

Kojima G., Iliffe S., Jivraj S. \& Walters K. (2016) Association between frailty and quality of life among community-dwelling older people: a systematic review and meta-analysis. Journal of Epidemiology and Community Health. doi:10.1136/jech-2015206717

Koller M.T., Raatz H., Steyerberg E.W. \& Wolbers M. (2012) Competing risks and the clinical community: irrelevance or ignorance? Statistics in Medicine 31, 1089-1097.

Koller M.T., Van Delden C., Muller N.J., Baumann P., Lovis C., Marti H.P., Fehr T., Binet I., De Geest S., Bucher H.C., Meylan P., Pascual M. \& Steiger J. (2013) Design and methodology of the Swiss Transplant Cohort Study (STCS): a comprehensive prospective nationwide long-term follow-up cohort. European Journal of Epidemiology 28, 347-355.

Koller M., Stampf S., Rick J., Achermann R. \& Steiger J. (2014) Swiss Transplant Cohort Study report (May 2008 - December 2013) [Online]. Retrieved from http://www.stcs.ch/publications/ stcs-reports/ on September 2015.

Kooman J.P., Kotanko P., Schols A.M., Shiels P.G. \& Stenvinkel P. (2014) Chronic kidney disease and premature ageing. Nature Reviews Nephrology 10, 732-742.

Kumnig M., Rumpold G., Hofer S., Konig P., Holzner B., Giesinger J., Gamper E.M., Zabernigg A. \& Hoflehner A. (2014) Patientreported outcome reference values for patients after kidney transplantation. Wiener Klinische Wochenschrift 126, 15-22.

Lai J.C., Feng S., Terrault N.A., Lizaola B., Hayssen H. \& Covinsky K. (2014a) Frailty predicts waitlist mortality in liver transplant candidates. American Journal of Transplantation 14, 1870-1879.

Lai X., Chen G., Qiu J., Wang C. \& Chen L. (2014b) Recipientrelated risk factors for graft failure and death in elderly kidney transplant recipients. PLOS ONE 9, e112938.
Lam M. \& Jassal S.V. (2015) The concept of frailty in geriatric chronic kidney disease (CKD) patients. Blood Purification 39, 50-54.

Lee Y.J., Chang J.H., Choi H.N., Jung J.Y., Kim Y.S., Chung W.K., Park Y.H. \& Lee H.H. (2012) Donor-recipient age difference and graft survival in living donor kidney transplantation. Transplantation Proceedings 44, 270-272.

Leng S.X., Xue Q.L., Tian J., Walston J.D. \& Fried L.P. (2007) Inflammation and frailty in older women. Journal of the American Geriatrics Society 55, 864-871.

Leng S.X., Xue Q.L., Tian J., Huang Y., Yeh S.H. \& Fried L.P. (2009) Associations of neutrophil and monocyte counts with frailty in community-dwelling disabled older women: results from the Women's Health and Aging Studies I. Experimental Gerontology 44, 511-516.

Li H., Manwani B. \& Leng S.X. (2011) Frailty, inflammation and immunity. Aging and Disease 2, 466-473.

Lyndon H. (2015) Reframing frailty as a long-term condition. Nursing Older People 27, 32-39.

Makary M.A., Segev D.L., Pronovost P.J., Syin D., Bandeen-Roche K., Patel P., Takenaga R., Devgan L., Holzmueller C.G., Tian J. \& Fried L.P. (2010) Frailty as a predictor of surgical outcomes in older patients. Journal of the American College of Surgeons 210, 901-908.

Marsicano Ede O., Fernandes Nda S., Colugnati F., Grincenkov F.R., Fernandes N.M., De Geest S. \& Sanders-Pinheiro H. (2013) Transcultural adaptation and initial validation of Brazilian-Portuguese version of the Basel assessment of adherence to immunosuppressive medications scale (BAASIS) in kidney transplants. BMC Nephrology 14, 108.

Mathiowetz V., Kashman N., Volland G., Weber K., Dowe M. \& Rogers S. (1985) Grip and pinch strength: normative data for adults. Archives of Physical Medicine and Rehabilitation 66(2), 69-74.

McAdams-Demarco M.A., Law A., Salter M.L., Boyarsky B., Gimenez L., Jaar B.G., Walston J.D. \& Segev D.L. (2013a) Frailty as a novel predictor of mortality and hospitalization in individuals of all ages undergoing hemodialysis. Journal of the American Geriatrics Society 61, 896-901.

McAdams-Demarco M.A., Law A., Salter M.L., Chow E., Grams M., Walston J. \& Segev D.L. (2013b) Frailty and early hospital readmission after kidney transplantation. American Journal of Transplantation 13, 2091-2095.

McAdams-Demarco M.A., Isaacs K., Darko L., Salter M.L., Gupta N., King E.A., Walston J. \& Segev D.L. (2015a) Changes in Frailty After Kidney Transplantation. Journal of the American Geriatrics Society 63, 2152-2157.

McAdams-Demarco M.A., Law A., King E., Orandi B., Salter M., Gupta N., Chow E., Alachkar N., Desai N., Varadhan R., Walston J. \& Segev D.L. (2015b) Frailty and mortality in kidney transplant recipients. American Journal of Transplantation 15, 149-154.

McAdams-Demarco M.A., Tan J., Salter M.L., Gross A., Meoni L.A., Jaar B.G., Kao W.H., Parekh R.S., Segev D.L. \& Sozio S.M. (2015c) Frailty and Cognitive Function in Incident Hemodialysis Patients. Clinical Journal of the American Society of Nephrology: CJASN 10, 2181-2189. 
Mehra M.R., Kobashigawa J., Starling R., Russell S., Uber P.A., Parameshwar J., Mohacsi P., Augustine S., Aaronson K. \& Barr M. (2006) Listing criteria for heart transplantation: International Society for Heart and Lung Transplantation guidelines for the care of cardiac transplant candidates-2006. Journal of Heart and Lung Transplantation 25, 1024-1042.

Molnar-Varga M., Molnar M.Z., Szeifert L., Kovacs A.Z., Kelemen A., Becze A., Laszlo G., Szentkiralyi A., Czira M.E., Mucsi I. \& Novak M. (2011) Health-related quality of life and clinical outcomes in kidney transplant recipients. American Journal of Kidney Diseases 58, 444-452.

Musso C.G., Jauregui J.R. \& Macias Nunez J.F. (2015) Frailty phenotype and chronic kidney disease: a review of the literature. International Urology and Nephrology 47(11), 1801-1807.

Nasreddine Z.S., Phillips N.A., Bedirian V., Charbonneau S., Whitehead V., Collin I., Cummings J.L. \& Chertkow H. (2005) The Montreal Cognitive Assessment, MoCA: a brief screening tool for mild cognitive impairment. Journal of the American Geriatrics Society 53, 695-699.

National Institute For Health Research \& Research Design Service London (2013) Patient and Public Involvement in Healt and Social Care research: a Handbook for Researchers by Research Design Service London. London. Retrieved from http:// www.rds.nihr.ac.uk/wp-content/uploads/RDS-PPI-Handbook-2014v8-FINAL.pdf on 12 March 2015.

Partridge J.S., Harari D. \& Dhesi J.K. (2012) Frailty in the older surgical patient: a review. Age and Ageing 41, 142-147.

Pascual J., Abramowicz D., Cochat P., Claas F., Dudley C., Harden P., Heeman U., Hourmant M., Maggiore U., Salvadori M., Spasovski G., Squif J.P., Steiger J., Torres A., Vanholder R., Van Biesen W., Viklicky O., Zeier M. \& Nagler E. (2014) European renal best practice guideline on the management and evaluation of the kidney donor and recipient. Nefrologia 34, 293-301.

Pinsky B.W., Takemoto S.K., Lentine K.L., Burroughs T.E., Schnitzler M.A. \& Salvalaggio P.R. (2009) Transplant outcomes and economic costs associated with patient noncompliance to immunosuppression. American Journal of Transplantation 9, 2597-2606.

Pintilie M. (2007) Analysing and interpreting competing risk data. Statistics in Medicine 26, 1360-1367.

Roberts H.C., Denison H.J., Martin H.J., Patel H.P., Syddall H., Cooper C. \& Sayer A.A. (2011) A review of the measurement of grip strength in clinical and epidemiological studies: towards a standardised approach. Age and Ageing 40(4), 423-429.

Robinson T.N., Walston J.D., Brummel N.E., Deiner S., Brown C.H.T., Kennedy M. \& Hurria A. (2015) Frailty for Surgeons: review of a National Institute on Aging Conference on Frailty for Specialists. Journal of the American College of Surgeons, 221, 1083-1092.

Roshanravan B., Khatri M., Robinson-Cohen C., Levin G., Patel K.V., De Boer I.H., Seliger S., Ruzinski J., Himmelfarb J. \& Kestenbaum B. (2012) A prospective study of frailty in nephrology-referred patients with CKD. American Journal of Kidney Diseases 60, 912-921.

Sanchez-Escuredo A., Alsina A., Diekmann F., Revuelta I., Esforzado N., Ricart M.J., Cofan F., Torregrosa J.V., Campistol J.M., Oppenheimer F. \& Fernandez E. (2015) Economic analysis of the treatment of end-stage renal disease treatment: livingdonor kidney transplantation versus hemodialysis. Transplantation Proceedings 47, 30-33.

Santesuisse (2016) Tarife und Leistungen. [online] Retrieved from https://www.santesuisse.ch/ on 10 May 2016.

Sapir-Pichhadze R., Pintilie M., Tinckam K.J., Laupacis A., Logan A.G., Beyene J. \& Kim S.J. (2016) Survival analysis in the presence of competing risks: the example of wait-listed kidney transplant candidates. American Journal of Transplantation 16(7), 19581966.

Secutrial (2000) Web-based Data Capture In Clinical Trials [Online]. Retrieved from http://www.secutrial.com/ on 18 January 2016.

Seiler A., Jenewein J., Martin-Soelch C., Goetzmann L., Inci I., Weder W., Schuurmans M., Benden C., Brucher A. \& Klaghofer R. (2015) Post-transplant outcome-clusters of psychological distress and health-related quality of life in lung transplant recipients. Swiss Medical Weekly 145, w14236.

Singer J.P., Diamond J.M., Gries C.J., Mcdonnough J., Blanc P.D., Shah R., Dean M.Y., Hersh B., Wolters P.J., Tokman S., Arcasoy S.M., Ramphal K., Greenland J.R., Smith N., Heffernan P., Shah L., Shrestha P., Golden J.A., Blumenthal N.P., Huang D., Sonett J., Hays S., Oyster M., Katz P.P., Robbins H., Brown M., Leard L.E., Kukreja J., Bacchetta M., Bush E., D’Ovidio F., Rushefski M., Raza K., Christie J.D. \& Lederer D.J. (2015) Frailty phenotypes, disability and outcomes in adult candidates for lung transplantation. American Journal of Respiratory and Critical Care Medicine 192(11), 1325-1334.

Singh P., Ng Y.H. \& Unruh M. (2016) Kidney transplantation among the elderly: challenges and opportunities to improve outcomes. Advances in Chronic Kidney Disease 23, 44-50.

Sirven N. \& Rapp T. (2014) The dynamics of hospital use among older people: evidence for Europe using SHARE data. Retrieved from http://lare-efi.u-bordeaux4.fr/IMG/pdf/SirvenRapp2014.pdf on March 2015. Document de Travail No 2014/01.

SwissDRG AG. (2016). SwissDRG aktuell. [online] Retrieved from http://www.swissdrg.org/de/index.asp?navid=0 on 20 June 2016.

Swiss Federal Statistical Office (2014) Wage levels in Switzerland. [online] Retrieved from https://www.bfs.admin.ch/bfs/en/ home.html on 13 May 2016.

SwissTransplant (2014). Year report. Retrieved from http://www. stcs.ch/research/publications on 3 March 2015.

Tan-Torres Edejer T., Baltussen R.B., Adam T., Hutubessy R., Acharay A., Evans D.B. \& Murray C.J.L. 2003. Making Choices in Health: WHO Guide to Cost-effetiveness Analysis. World Health Organization, Geneva.

Theou O. \& Rockwood K. (2015) Frailty in Aging: Biological, Clinical and Social Implications. Basel, Karger.

Theou O., Cann L., Blodgett J., Wallace L.M., Brothers T.D. \& Rockwood K. (2015) Modifications to the frailty phenotype criteria: Systematic review of the current literature and investigation of 262 frailty phenotypes in the Survey of Health, Ageing and Retirement in Europe. Ageing Research Reviews 21, 78-94.

Tiffin-Richards F.E., Costa A.S., Holschbach B., Frank R.D., Vassiliadou A., Kruger T., Kuckuck K., Gross T., Eitner F., Floege J., Schulz J.B. \& Reetz K. (2014) The Montreal Cognitive Assessment (MoCA) - a sensitive screening instrument for 
detecting cognitive impairment in chronic hemodialysis patients. PLOS ONE 9, e106700.

United Network for Organ Sharing (UNOS) - Organ Procurement and Transplantation Network (OPTN) (2014) OPTN Policies, Policy 14: Living Donation. [Online]. Retrieved from http:// optn.transplant.hrsa.gov/ContentDocuments/OPTN_Policies.pdf on 17 November 2015.

Van Sandwijk M.S., Ten Berge I.J., Majoie C.B., Caan M.W., De Sonneville L.M., Van Gool W.A. \& Bemelman F.J. (2015) Cognitive changes in chronic kidney disease and after transplantation. Transplantation 100(4), 734-742.

Walston J.D. \& Bandeen-Roche K. (2015) Frailty: a tale of two concepts. BMC Medicine 13, 185.

Wilson M.E., Vakil A.P., Kandel P., Undavalli C., Dunlay S.M. \& Kennedy C.C. (2016) Pretransplant frailty is associated with decreased survival after lung transplantation. Journal of Heart and Lung Transplantation 35, 173-178.

Wolbers M., Koller M.T., Stel V.S., Schaer B., Jager K.J., Leffondre K. \& Heinze G. (2014) Competing risks analyses: objectives and approaches. European Heart Journal 35, 2936-2941.

Wong G., Howard K., Webster A.C., Morton R.L., Chapman J.R. \& Craig J.C. (2014) How is Health Economics Relevant to Transplant Clinicians? Transplantation 98, 124-130.

Wu K., Budde K., Lu H., Schmidt D., Liefeldt L., Glander P., Neumayer H.H. \& Rudolph B. (2014) The severity of acute cellular rejection defined by Banff classification is associated with kidney allograft outcomes. Transplantation 97(11), 1146-1154.

Wu K., Budde K., Schmidt D., Neumayer H.H. \& Rudolph B. (2015) The relationship of the severity and category of acute rejection with intimal arteritis defined in Banff classification to clinical outcomes. Transplantation 99(8), e105-114.

Yassuda M.S., Lopes A.J., Cachioni M., Falcao D.V., Batistoni S.S. \& Guimaraes V.A. (2012) Frailty criteria and cognitive performance are related: data from the FIBRA study in Ermelino Matarazzo, São Paulo, Brazil. Journal of Nutrition Health Aging $16,55-61$.

\section{Appendix}

\section{GERAS Study Consortium Members}

Kidney transplant patients, the Swiss Kidney Patient Association, nursing, medical and allied health professionals, regional and national governing bodies and policy makers.

\section{Psychosocial Interest Group of the STCS}

Berben Lut, Burkhalter Hanna, Claes Veerle, De Geest Sabina, Denhaerynck Kris, Helmy Remon, Kirsch Monika, Leppla
Lynn, Mauthner Oliver, Struker Marian (University of Basel); Boehler Annette, Gerull Sabine, Koller Michael T (University Hospital Basel); Huynh-Do Uyen (University Hospital Inselspital Bern); Boely Elsa (University Hospital Geneva); Catana Emmanuelle (University Hospital Lausanne); Simcox Amira (University of Lausanne); Seiler Annina, Klaghofer Richard (University Hospital Zurich); Binet Isabelle, Künzler-Heule Patrizia (Cantonal Hospital St. Gallen); Beckmann Sonja (University of Basel, University Hospital Zurich)

\section{STCS Members}

This study is being conducted within the framework of the Swiss Transplant Cohort Study, supported by the Swiss National Science Foundation and the Swiss University Hospitals (G15) and transplant centres. The members of the Swiss Transplant Cohort Study are: Rita Achermann, Patrizia Amico, John-David Aubert, Philippe Baumann, Guido Beldi, Christian Benden, Christoph Berger, Isabelle Binet, Pierre-Yves Bochud, Elsa Boely, Heiner Bucher, Leo Bühler, Thierry Carell, Emmanuelle Catana, Yves Chalandon, Sabina De Geest, Olivier de Rougemont, Michael Dickenmann, Michel Duchosal, Thomas Fehr, Sylvie Ferrari-Lacraz, Christian Garzoni, Paola Gasche Soccal, Emiliano Giostra, Déla Golshayan, Karine Hadaya, Jörg Halter, Dominik Heim, Christoph Hess, Sven Hillinger, Hans H. Hirsch, Günther Hofbauer, Uyen Huynh-Do, Franz Immer, Richard Klaghofer, Michael Koller (Head of the data centre), Bettina Laesser, Roger Lehmann, Christian Lovis, Oriol Manuel, Hans-Peter Marti, Pierre Yves Martin, Luca Martinolli, Pascal Meylan (Head, Biological samples management group), Paul Mohacsi, Isabelle Morard, Philippe Morel, Ulrike Mueller, Nicolas J Mueller (Chairman Scientific Committee), Helen Mueller-McKenna (Head of local data management), Antonia Müller, Thomas Müller, Beat Müllhaupt, David Nadal, Manuel Pascual (Executive office), Jakob Passweg, Chantal Piot Ziegler, Juliane Rick, Eddy Roosnek, Anne Rosselet, Silvia Rothlin, Frank Ruschitzka, Urs Schanz, Stefan Schaub, Aurelia Schnyder, Christian Seiler, Susanne Stampf, Jürg Steiger (Head, Executive Office), Guido Stirnimann, Christian Toso, Christian Van Delden (Executive office), Jean-Pierre Venetz, Jean Villard, Madeleine Wick (STCS coordinator), Markus Wilhelm, Patrick Yerly. 
The Journal of Advanced Nursing (JAN) is an international, peer-reviewed, scientific journal. JAN contributes to the advancement of evidence-based nursing, midwifery and health care by disseminating high quality research and scholarship of contemporary relevance and with potential to advance knowledge for practice, education, management or policy. JAN publishes research reviews, original research reports and methodological and theoretical papers.

For further information, please visit JAN on the Wiley Online Library website: www.wileyonlinelibrary.com/journal/jan

$\underline{\text { Reasons to publish your work in JAN: }}$

- High-impact forum: the world's most cited nursing journal, with an Impact Factor of 1.917 - ranked 8/114 in the 2015 ISI Journal Citation Reports (C) (Nursing (Social Science)).

- Most read nursing journal in the world: over 3 million articles downloaded online per year and accessible in over 10,000 libraries worldwide (including over 3,500 in developing countries with free or low cost access).

- Fast and easy online submission: online submission at http://mc.manuscriptcentral.com/jan.

- Positive publishing experience: rapid double-blind peer review with constructive feedback.

- Rapid online publication in five weeks: average time from final manuscript arriving in production to online publication.

- Online Open: the option to pay to make your article freely and openly accessible to non-subscribers upon publication on Wiley Online Library, as well as the option to deposit the article in your own or your funding agency's preferred archive (e.g. PubMed). 